
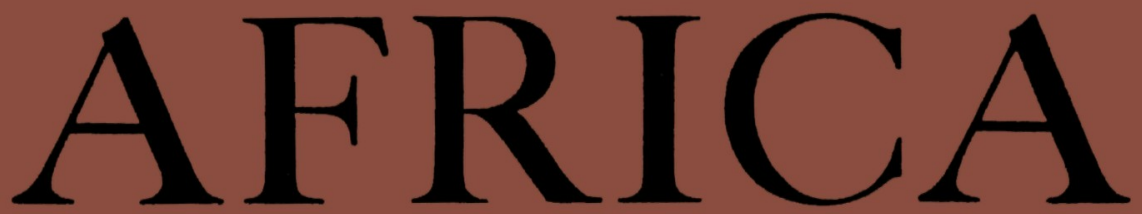

JOURNAL OF THE INTERNATIONAL INSTITUTE OF AFRICAN LANGUAGES AND CULTURES

JOURNAL DE L'INSTTTUT INTERNATIONAL DES LANGUES E'T CIVILISATIONS AFRICAINES ZEITSCHRIFT DES INTERNATIONALEN INSTITUTS FÜR AFRIKANISCHE SPRACHEN UND KULTUREN

\author{
Editor \\ DIEDRICH WESTERMANN \\ Assistant Editor \\ D. G. BRACKETT
}

Price

Six Shillings Net

OXFORD UNIVERSITY PRESS LONDON : HUMPHREY MILFORD 


\section{CONTENTS OF THIS NUMBER}

THE MORAL CODE OF THE NGONI AND THEIR FORMER MILITARY STATE. Margaret Read

SOCIAL ASPECTS OF FIRST FRUITS CEREMONIES AMONG THE SOUTH-EASTERN BANTU. Max Gluckmann " 25

LES SOCIÉTÉS BERBERES DANS L'AURĖS MÉRIDIONAL. G. Tillion

ANCIENT AND MODERN ART IN BENIN CITY. Eckart von Sydow

THE 'NATIVE' NEWSPAPER. T. Cullen Young THE TEACHING OF AFRICAN LANGUAGES IN AFRICAN SCHOOLS. A Need for Improvement. A. V. P. Elliott $\quad " 73$ THE STORIES OF THE KIKUYU. Leonard J. Beecher LA POLITIQUE BRITANNIQUE EN NIGÉRIA. Henri Labouret „ 88 ANNUAL REPORT. THE WORK OF THE INSTITUTE IN $1937, " 90$ MEMBERS ELECTED BY THE EXECUTIVE COUNCIL, OCTOBER 1937

NINTH PRIZE COMPETITION FOR BOOKS IN AFRICAN LANGUAGES

EDUCATION IN EAST AFRICA (Dr. L. P. Mair); History TEXT-HOOKS FOR SCHOOIS IN BRITISH THOPICAL AFRICA; SOUTH AFRICAN INSTITUTE OF RACE helations; Li Style oral r.n aprique (Professeut N. De Cleene); rostunMOTHERS IN AIRICA (LACTATIO SEROTINA); TOGBA, A WOMEN'S SOCIETY IN liberia (Frl. Etta Donner); the ENERgetic pHILOSOPIIY OF PRIMITIVE MaN; AN ANTHROPOLOGical EXPEDITION TO TANGANYIKa (Dr. L. Kohl-Iatsen)

REVIEWS OF BOOKS

a tribal survey of moncialla province, edited by L. F. Nalder (D. Westermann); FAMILIL, VOLK UND STAAT IN IIHEN GESELLSCIIAFTLICIIEN LTERENVORGÄNGEN, von $A$. Vierkandt (P. von Werder); LES GRANDES LIGNES DES MIGR.ATIONS DES DANTOUS DE LA PROVINCE ORIENTALE DU CONGO BEL.GE, par A. Moeller (N. De Cleene); ABessinies, von Prof. Dr. Enno Littmamn (Erich Sander); IM LANDE IDLS GADA, WANIDERUNGEN ZWISCIIEN VOLKStrümalern sǘdabessiniens, von $D r$. Ad. E. Jensen (W. Schilde); lingala grammar aND Dictionary, edited by C. Malcolm Guthrie (E. L. Rapp); THE PHONETIC; STRUCTURE OF SOMALI, by E. Lilias Alrmstrong (J. Lukas); RASSENLND VOLKERKINDE, L.EBENSPROBLEME DIR RASSEN, GESHLLLCHAFTEN UND vOLKER, von WV. E. Mählmann (D. Westermann); STONL ACE AFRICA, AN OUTLINE OR PREHISTORY IN AFRICA, by L.S. B. Leakey (F. Rudolf I.ehmann);

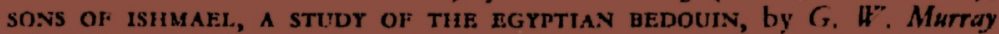
(E. E. Evans-Pritchard) 


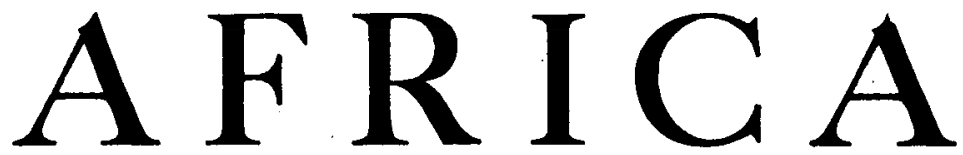

JOURNAL OF THE INTERNATIONAL INSTITUTE OF AFRICAN LANGUAGES AND CULTURES JOURNAL DE L'INSTITUT INTERNATIONAL DES LANGUES ET CIVILISATIONS AFRICAINES ZEITSCHRIFT DES INTERNATIONALEN INSTITUTS FÜR AFRIKANISCHE SPRACHEN UND KULTUREN

\title{
Editor
}

\section{DIEDRICH WESTERMANN}

\author{
Assistant Editor \\ D. G. BRACKETT
}

VOLUME XI

1938

OXFORD UNIVERSITY PRESS

LONDON : HUMPHREY MILFORD 
PRINTED IN GREAT BRITAIN 


\section{CONTENTS}

The Moral Code of the Ngoni and their former Military State. Margaret Read . . . . . . . . . . I

Social Aspects of First Fruits Ceremonies among the South-Eastern

Bantu. Max Gluckmann . . . . . . . 25

Les Sociétés Berbères dans l'Aurès Méridional. G. Tillion . 42

Ancient and Modern Art in Benin City. Eckart von Sydow . . ss

The 'Native' Newspaper. T. Cullen Young . . . . . . . . 63

The Teaching of African Languages in African Schools: A Need for

Improvement. A. V. P. Elliott . . . . . . 73

The Stories of the Kikuyu. Leonard J. Beecher . . . . 80

La Politique Britannique en Nigéria. Henri Labouret . . . $\quad 88$

Annual Report: the Work of the Institute in 1937 . . . . 90

Members elected by the Executive Council, October 1937 • $\quad$. $\quad 98$

Ninth Prize Competition for Books in African Languages . . 99

Notes and News.

Reviews of Books . . . . . . . . . . . . . . . . .

Contributors to this Number $\quad$. $\quad$. $\quad$. $\quad . \quad$. . . . 124

Bibliography of Current Literature dealing with African Languages and Cultures . . . . . . . . . 125

Kinship Organization of the Banyankole. Kalervo Oberg . . . 129

L'Alimentation des Autochtones dans les Possessions Tropicales.

Henri Labouret . . . . . . . . . . 160

The African in Transition: Some Comparisons with Melanesia. Richard

C. Thurnwald . . . . . . . . . . 174

The Problem of Mass Education in Africa. W. Bryant Mumford and

R. Jackson . . . . . . . . . . . $\quad$. 187

Das Leben des Kindes im Nsungli-Stamm. D. und J. Sieber . . 208

The Teaching of African Languages in Schools: A Note on the Position

in Kenya. William H. Laughton . . . . • . . 22x

Notes and News.

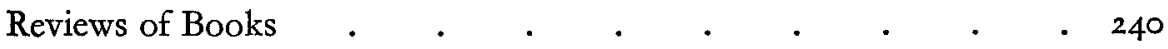

Contributors to this Number . . . . . . . . 256 
Bibliography of Current Literature dealing with African Languages and Cultures

The Place of the North-Eastern Transvaal Sotho in the South Bantu Complex. Eileen Jensen Krige .

L'Habitation chez les Ouled Abderrahman Chaouia del'Aurès. Thérèse Western Contact. James W. C. Dougall .

\section{Rivière. \\ The Development of the Education of the African in Relation to}

Property among the Ciga in Uganda. May Mandelbaum Edel

The Marriage Customs of the Ovimbundu. Raul Kavita Evambi, trans-

lated by Merlin W. Ennis

Notes and News.

Reviews of Books . $\quad . \quad$. $\quad . \quad$. $\quad . \quad$. $\quad .364$

Bibliography of Current Literature dealing with African Languages and Cultures

Contributors to this Number

Native Standards of Living and African Culture Change. Margaret Read

(Supplement)

Native Education at the Cross-roads in South Africa. R. F. Alfred

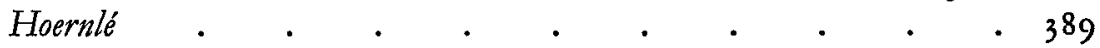

The Study of Native Court Records as a Method of Ethnological Inquiry. R. de Z. Hall .

A Tribal Market in the Spanish Zone of Morocco. W. Fogg • $\quad 428$

Evil and Witcheraft among the Ndogo Group of Tribes. Fr. S.

Santandrea . . .

L'Enfant chez les Sénoufos de la Côte d'Ivoire. P. Knops . $\quad$. 482

Executive Council: Report of the Seventeenth Meeting . • . 493

Members Elected by the Executive Council: June 1938 . . . 502

Notes and News.

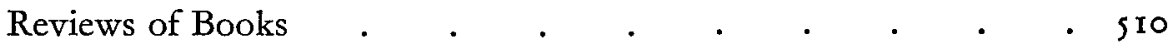

Bibliography of Current Literature dealing with African Languages and Cultures . . . . . . . . . . 518

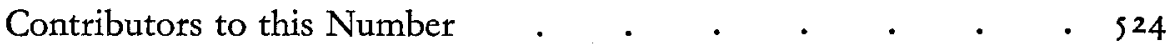

Social and Psychological Aspects of Education in Taleland. M. Fortes

(Supplement)

Index 